\title{
Fast and accurate identification of cryptic and sympatric mayfly species of the Baetis rhodani group
}

\author{
Roberta Bisconti ${ }^{*}$ (D), Roberta Tenchini, Carlo Belfiore, Giuseppe Nascetti and Daniele Canestrelli
}

\begin{abstract}
Objective: Species of the Baetis rhodani group are among the most widespread mayflies of the Palearctic region. However, frequent occurrence of morphologically cryptic species complicates the identification of sympatric species. Here, we proposed and tested a method for the fast, accurate, and cost-effective assignment of a large number of individuals to their putative species, based on high resolution melting profiles of a standard mitochondrial gene fragment. We tested this method using a system of three recently identified cryptic species inhabiting the Tyrrhenian Islands (western Mediterranean basin).
\end{abstract}

Results: Highly species-specific high resolution melting profiles were obtained, allowing the unequivocal attribution of each individual to the respective species. This assay provides a convenient and easily customizable alternative to traditional barcoding approaches, provided that the mayfly taxa occurring within the geographic area of interest have been previously identified and their high resolution melting profiles assessed.

Keywords: High resolution melting (HRM) curve, Species identification, Baetis rhodani, Tyrrhenian islands, Real time PCR

\section{Introduction}

Baetis rhodani (Pictet 1843) is a complex of morphologically cryptic mayfly species widespread in the Palearctic region [1]. Despite a considerable research effort in recent years [2-5], current knowledge of the phylogenetic relationships within this group and the taxonomic status of several of its representatives remain incomplete, with new species emerging as new areas of the Palearctic are investigated.

Methods of species recognition and individual assignment in mayflies have been mostly based on two distinct approaches, each one with its own advantages and drawbacks. The first and more traditional approach is based on the analysis of morphological diagnostic traits, primarily of the larval stages $[6,7]$. Although relatively inexpensive and time-saving, this approach relies entirely on an expert knowledge of the taxonomic group

*Correspondence: bisconti@unitus.it

Dipartimento di Scienze Ecologiche e Biologiche, Università degli Studi della Tuscia, Viale dell'Università s.n.c., 01100 Viterbo, Italy under study. Most importantly, with the advent of the second approach, molecular taxonomy, morphological approaches have soon appeared largely to underestimate the amount of species diversity within baetidae mayflies, including $B$. rhodani [2]. Indeed, under the single morphological species $B$. rhodani, several deeply divergent species have recently been recognized using molecular markers [2-5], and even more are likely to be described in the near future. On the other hand, molecular methods, such as those based on DNA barcodes, entail unprecedented processing costs per sample, and their extensive use for the preliminary phase of species delimitation has been largely debated (see $[8,9]$ ).

Recently, three endemic species belonging to the $B$. rhodani species group have been identified within the Tyrrhenian Islands, based on a multi-locus analysis of genetic variation among 112 individuals from 28 populations [5]. However, to obtain a careful characterization of the respective distribution ranges, patterns of co-occurrence on single islands, relative abundance in sites of cooccurrence, as well as for all subsequent ecological and 
evolutionary investigations on these species, the characterization of a much larger sample of individuals and populations will be mandatory. Since nuclear and mitochondrial patterns of variation were largely congruent to one another in this group of species [5], the use of a DNA barcoding approach would be fully suitable.

We developed and validated a method for the assignment of a large number of individual mayflies to their putative species, based on the analysis of the high-resolution melting (HRM) curve of a standard molecular marker (NADH dehydrogenase subunit 1 gene). HRM is an effective, still not fully exploited, acquisition in the molecular taxonomy toolbox (see e.g. [10, 11]), which allows to assess the occurrence of sequence differences of diagnostic value between taxa, based on melting temperature profiles and the associated fluorescence peaks. Although based on a DNA barcoding approach, this method is faster, more cost-effective, and equally accurate when compared with traditional sequence-based approaches, provided that the pattern of variation within the focal taxa has already been characterized, as is the case for the B. rhodani group on the Tyrrhenian Islands [5].

\section{Main text \\ Methods}

In total, 399 larvae-100 individuals from a previous study [5] and 299 new samples-of the Baetis rhodani species group were collected from 59 localities (Table 1, Fig. 1) spanning the three main Tyrrhenian Islands (Sardinia, Corsica and Elba islands; no ethical approval is needed for sampling or processing these invertebrate species). The larvae were preserved in $95 \% \mathrm{ETOH}$ prior to DNA extraction. A formal species description of the three species occurring in the study area is still pending. For consistency with the previous work which identified them as distinct biological species, we will refer to them here as Species A, Species B, and Species C. An unequivocal species assignment was made possible by the deep mitochondrial sequence divergence observed between the three species. Indeed, the percent sequence divergence between species ( $p$-distance) was as follows [5]: A vs $B=14 \%$, $A$ vs $C=29 \%$, and $B$ vs $C=26 \%$.

Total genomic DNA extraction was carried out from the thorax, legs, or entire larval body by proteinase $\mathrm{K}$ (Promega) digestion and a standard phenol-chloroform protocol [12]. The amount of genomic DNA of each sample was assessed with the Qubit 2.0 fluorometer (Invitrogen, Carlsbad, CA, USA), using the Qubit dsDNA BR Assay kit (Thermo Fisher Scientific Inc.). Each sample was then concentrated to $10 \mathrm{ng} / \mu \mathrm{L}$ for downstream analyses.
Table 1 Geographic location and sample size (n) of the 59 sites sampled within the Tyrrhenian Islands

\begin{tabular}{|c|c|c|c|}
\hline Island & Latitude $\mathrm{N}$ & Longitude $\mathrm{E}$ & $\mathrm{n}$ \\
\hline \multicolumn{4}{|l|}{ Sardinia } \\
\hline 1 & $41^{\circ} 6.611^{\prime}$ & $9^{\circ} 13.731^{\prime}$ & 1 \\
\hline 2 & $41^{\circ} 5.569^{\prime}$ & $9^{\circ} 14.757^{\prime}$ & 3 \\
\hline 3 & $41^{\circ} 3.825^{\prime}$ & $9^{\circ} 24.300^{\prime}$ & 4 \\
\hline 4 & $41^{\circ} 2.900^{\prime}$ & $9^{\circ} 19.756^{\prime}$ & 6 \\
\hline 5 & $40^{\circ} 46.235^{\prime}$ & $9^{\circ} 32.380^{\prime}$ & 4 \\
\hline 6 & $40^{\circ} 28.613^{\prime}$ & $9^{\circ} 7.766^{\prime}$ & 2 \\
\hline 7 & $40^{\circ} 22.751^{\prime}$ & $9^{\circ} 26.065^{\prime}$ & 10 \\
\hline 8 & $40^{\circ} 2.221^{\prime}$ & $9^{\circ} 15.438^{\prime}$ & 6 \\
\hline 9 & $40^{\circ} 2.752^{\prime}$ & $9^{\circ} 31.012^{\prime}$ & 10 \\
\hline 10 & $40^{\circ} 1.237^{\prime}$ & $9^{\circ} 31.922^{\prime}$ & 5 \\
\hline 11 & $39^{\circ} 57.661^{\prime}$ & $9^{\circ} 32.632^{\prime}$ & 2 \\
\hline 12 & $39^{\circ} 57.625^{\prime}$ & $9^{\circ} 33.680^{\prime}$ & 4 \\
\hline 13 & $39^{\circ} 57.097^{\prime}$ & $9^{\circ} 36.282^{\prime}$ & 2 \\
\hline 14 & $39^{\circ} 56.477^{\prime}$ & $9^{\circ} 34.785^{\prime}$ & 10 \\
\hline 15 & $39^{\circ} 55.590^{\prime}$ & $9^{\circ} 38.244^{\prime}$ & 4 \\
\hline 16 & $39^{\circ} 53.738^{\prime}$ & $9^{\circ} 11.561^{\prime}$ & 10 \\
\hline 17 & $39^{\circ} 49.494^{\prime}$ & $9^{\circ} 12.106^{\prime}$ & 10 \\
\hline 18 & $39^{\circ} 30.284^{\prime}$ & $9^{\circ} 8.095^{\prime}$ & 8 \\
\hline 19 & $39^{\circ} 23.525^{\prime}$ & $8^{\circ} 40.131^{\prime}$ & 6 \\
\hline 20 & $39^{\circ} 30.210^{\prime}$ & $8^{\circ} 37.196^{\prime}$ & 2 \\
\hline 21 & $39^{\circ} 33.355^{\prime}$ & $8^{\circ} 59.529^{\prime}$ & 7 \\
\hline 22 & $40^{\circ} 8.863^{\prime}$ & $8^{\circ} 32.295^{\prime}$ & 7 \\
\hline 23 & $40^{\circ} 14.036^{\prime}$ & $8^{\circ} 35.382^{\prime}$ & 9 \\
\hline 24 & $40^{\circ} 24.421^{\prime}$ & $8^{\circ} 37.614^{\prime}$ & 8 \\
\hline 25 & $40^{\circ} 35.799^{\prime}$ & $8^{\circ} 38.053^{\prime}$ & 9 \\
\hline 26 & $40^{\circ} 31.236^{\prime}$ & $8^{\circ} 52.058^{\prime}$ & 10 \\
\hline 27 & $41^{\circ} 5.433^{\prime}$ & $9^{\circ} 14.119^{\prime}$ & 6 \\
\hline \multicolumn{4}{|l|}{ Corsica } \\
\hline 28 & $42^{\circ} 48.760^{\prime}$ & $9^{\circ} 28.427^{\prime}$ & 12 \\
\hline 29 & $42^{\circ} 35.515^{\prime}$ & $9^{\circ} 21.799^{\prime}$ & 4 \\
\hline 30 & $42^{\circ} 30.267^{\prime}$ & $9^{\circ} 22.517^{\prime}$ & 9 \\
\hline 31 & $42^{\circ} 26.069^{\prime}$ & $9^{\circ} 13.433^{\prime}$ & 4 \\
\hline 32 & $42^{\circ} 18.291^{\prime}$ & $9^{\circ} 8.779^{\prime}$ & 9 \\
\hline 33 & $42^{\circ} 16.504^{\prime}$ & $9^{\circ} 6.438^{\prime}$ & 5 \\
\hline 34 & $42^{\circ} 11.860^{\prime}$ & $9^{\circ} 7.299^{\prime}$ & 3 \\
\hline 35 & $42^{\circ} 6.869^{\prime}$ & $9^{\circ} 11.006^{\prime}$ & 2 \\
\hline 36 & $42^{\circ} 6.153^{\prime}$ & $9^{\circ} 14.679^{\prime}$ & 8 \\
\hline 37 & $42^{\circ} 0.990^{\prime}$ & $9^{\circ} 2.884^{\prime}$ & 5 \\
\hline 38 & $41^{\circ} 49.292^{\prime}$ & $9^{\circ} 15.599^{\prime}$ & 7 \\
\hline 39 & $41^{\circ} 46.110^{\prime}$ & $9^{\circ} 10.407^{\prime}$ & 10 \\
\hline 40 & $41^{\circ} 41.447^{\prime}$ & $9^{\circ} 9.113^{\prime}$ & 10 \\
\hline 41 & $41^{\circ} 37.541^{\prime}$ & $9^{\circ} 4.962^{\prime}$ & 7 \\
\hline 42 & $41^{\circ} 39.831^{\prime}$ & $9^{\circ} 0.889^{\prime}$ & 8 \\
\hline 43 & $41^{\circ} 57.634^{\prime}$ & $9^{\circ} 0.340^{\prime}$ & 4 \\
\hline 44 & $42^{\circ} 3.578^{\prime}$ & $8^{\circ} 57.781^{\prime}$ & 8 \\
\hline 45 & $42^{\circ} 2.975^{\prime}$ & $8^{\circ} 47.106^{\prime}$ & 7 \\
\hline
\end{tabular}


Table 1 continued

\begin{tabular}{cccr}
\hline Island & Latitude N & Longitude E & n \\
\hline 46 & $42^{\circ} 10.170^{\prime}$ & $8^{\circ} 49.200^{\prime}$ & 9 \\
47 & $42^{\circ} 14.317^{\prime}$ & $8^{\circ} 50.838^{\prime}$ & 9 \\
48 & $42^{\circ} 17.714^{\prime}$ & $8^{\circ} 42.141^{\prime}$ & 10 \\
49 & $42^{\circ} 22.993^{\prime}$ & $8^{\circ} 41.940^{\prime}$ & 4 \\
50 & $42^{\circ} 21.865^{\prime}$ & $8^{\circ} 48.113^{\prime}$ & 6 \\
51 & $42^{\circ} 29.176^{\prime}$ & $8^{\circ} 48.176^{\prime}$ & 8 \\
52 & $42^{\circ} 28.076^{\prime}$ & $9^{\circ} 6.385^{\prime}$ & 8 \\
53 & $42^{\circ} 37.292^{\prime}$ & $8^{\circ} 59.813^{\prime}$ & 8 \\
54 & $42^{\circ} 36.138^{\prime}$ & $9^{\circ} 8.313^{\prime}$ & 8 \\
55 & $42^{\circ} 34.182^{\prime}$ & $9^{\circ} 18.256^{\prime}$ & 11 \\
Elba & & & \\
56 & $42^{\circ} 47.379^{\prime}$ & $10^{\circ} 7.370^{\prime}$ & 5 \\
57 & $42^{\circ} 47.064^{\prime}$ & $10^{\circ} 9.962^{\prime}$ & 10 \\
58 & $42^{\circ} 44.556^{\prime}$ & $10^{\circ} 10.353^{\prime}$ & 6 \\
59 & $42^{\circ} 44.298^{\prime}$ & $10^{\circ} 10.604^{\prime}$ & 10 \\
\hline
\end{tabular}

Real-time quantitative PCR assays were carried out in 96-well plates through amplification of the mitochondrial NADH dehydrogenase subunit 1 gene (ND1) fragment with the following primers: ND1F (TAAAGTTAGCAGGTTCATACCC) and ND1R (CACCTATATTTGTACTTTGAAGG). Amplifications were run in a $15-\mu \mathrm{l}$ reaction volume containing $\mathrm{MgCl}_{2}$ (2 $\mathrm{mM}$, Promega), four dNTPs (0.2 mM each, Promega), two primers (0.2 $\mu \mathrm{M}$ each, Sigma-Aldrich), the enzyme Hotstart Taq polymerase (0.5 U, Promega), the reaction buffer $(1 \times$, Promega), EvaGreen ${ }^{\circledR}$ dye $(1 \times$, Biotium), and $\sim 10-30 \mathrm{ng}$ of DNA template.

Real time PCRs were run using a Roche LightCycler ${ }^{\circledR}$ LC480. The PCR cycling conditions were as follows: an initial step of $5 \mathrm{~min}$ at $95^{\circ} \mathrm{C}, 35$ cycles of $1 \mathrm{~min}$ at $94{ }^{\circ} \mathrm{C}$, $45 \mathrm{~s}$ at $57{ }^{\circ} \mathrm{C}$, and $90 \mathrm{~s}$ at $72{ }^{\circ} \mathrm{C}$, and an extension step of $10 \mathrm{~min}$ at $72{ }^{\circ} \mathrm{C}$. A final melting cycle was performed for $3 \mathrm{~min}$ at $95{ }^{\circ} \mathrm{C}$ and a melt from 40 to $95^{\circ} \mathrm{C}$ collecting fluorescence continuously at a ramping rate of $0.1^{\circ} \mathrm{C}$ per second. The HRM peaks obtained from single individuals were examined after each real-time PCR using the LightCycler $^{\circledR} 480$ Software (release version 1.5.0).

In order to characterize the HRM curve profiles of each species, we included in the analyses all the individuals belonging to the three species analysed in the previous study ( $\mathrm{n}=100$; [5]), where the diagnostic value of sequence variation among the three species was assessed. To further test the accuracy of the proposed method, we randomly selected and sequenced 24 individuals from the pool of newly screened samples (Genebank Accession Numbers: MG581893-MG581916). We then compared their species assignment based on HRM profiles to those achieved through standard sequencing.
In order to evaluate the diagnostic ability of the HRM curve method for the three species studied, we performed a principal component analysis (PCA) using the IBM SPSS v. 23 (IBM SPSS Statistics for Windows, Armonk, NY: IBM Corp), based on peak temperature and fluorescence values of the 100 individuals from the previous paper [5]. The first principal component was then used to perform a receiver operating characteristic (ROC) curve analysis, whose accuracy was evaluated by means of the area under the curve (AUC) values.

\section{Results and discussion}

The derived HRM curves obtained for the individuals already sequenced from a previous study clearly showed three distinct profiles (see Fig. 2a). A comparison of these profiles with the standard sequence-based species identification unequivocally indicated the diagnostic value of the HRM curves. This facilitated assigning each unique profile to one of the three species, without misidentifications.

The three HRM curves observed within the negative first-derivative plot were easily distinguishable from one another, based on curve shape and melting peak values (Fig. 2a). The curve identifying Species A showed two peaks, the first at $83^{\circ} \mathrm{C}$ with a maximum value of 17.3 and a minimum value of $12.8(-\mathrm{dF} / \mathrm{dT})$, and the second peak at $86{ }^{\circ} \mathrm{C}$ with a maximum value of 20.5 and a minimum value of $8.6(-\mathrm{dF} / \mathrm{dT})$. The HRM curve for Species B was diagnosable by a single peak at $83-84{ }^{\circ} \mathrm{C}$ with a maximum value of 28.4 and a minimum value of $19.7(-\mathrm{dF} /$ $\mathrm{dT}$ ). Finally, the HRM profile for Species $\mathrm{C}$ showed both the highest and narrowest curve profile, with a melting peak at $82{ }^{\circ} \mathrm{C}$ and a maximum value of 41.6 and a minimum value of $29.6(-\mathrm{dF} / \mathrm{dT})$. As shown by the scatterplot in Fig. 2b (see also Additional file 1), inter-individual variation within each species did not affect the diagnostic significance of the individual peak values.

The analysis of the 399 samples collected throughout the Tyrrhenian Islands (Sardinia, Corsica and Elba islands) did not reveal any new patterns for the HRM curve profiles in addition to the three described above. We assigned all analysed samples to a putative species: 128 to Species A, 170 to Species B, and 101 to Species C. As expected, based on the absence of new HRM curve variants among the newly studied samples, sequencebased assignment of all 24 individuals used as the control perfectly matched species identity as defined by melting profiles. Moreover, the ROC curve analysis based on the first principal component (variance explained: $82 \%$ ) strongly supported the diagnostic ability of HRM method used, showing extremely high values of the AUC, in all pairwise comparisons between species (range of the AUC values: $0.97-1.00)$. 


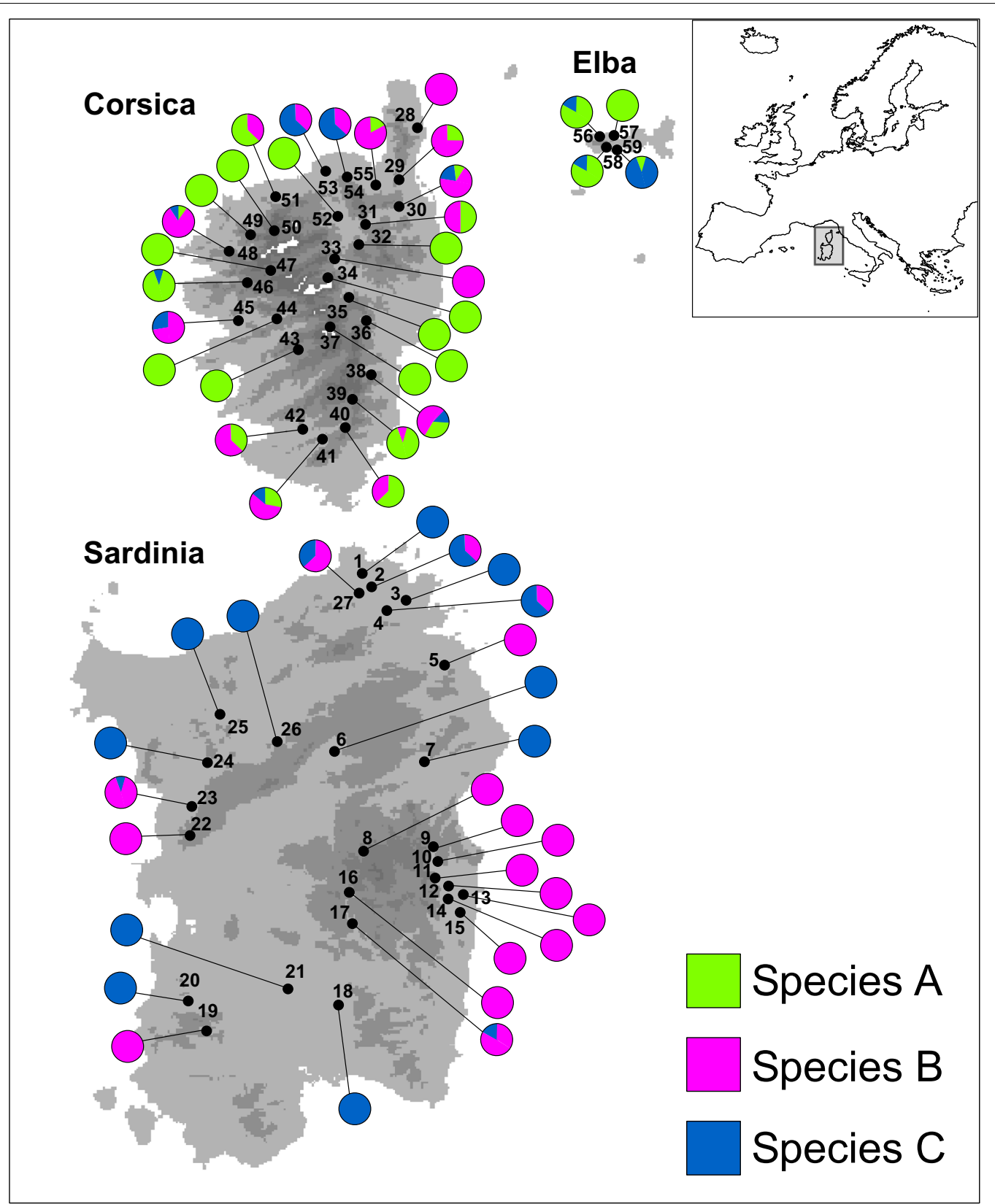

Fig. 1 Geographic location of the 59 sites sampled within the Tyrrhenian Islands. Localities are numbered as in Table 1. Pie diagrams show the proportion of individuals belonging to the three species within each sampled locality. (The digital elevation model was downloaded by the WorldClim 1.4 database, freely available at www.worldclim.org)

Our results clearly demonstrated that the HRM-based method proposed here to assess species identity for mayflies of the $B$. rhodani group on the Tyrrhenian Islands, proved as accurate and reliable as the standard sequencebased approach, besides allowing to avoid sequencing costs and efforts.

We utilized this method for a fast and accurate evaluation of the actual geographic distribution of the three cryptic species, which is fundamental information for any future study employing these species as target organisms. The results of this evaluation revealed distinct distribution patterns for the three studied species (Fig. 1), allowing us to incorporate them within a long-term study on the evolution of the insular biota (see also [13-19], to investigate species-specific eco-evolutionary dynamics, and to improve ongoing bio-monitoring programs in the area [20]. 


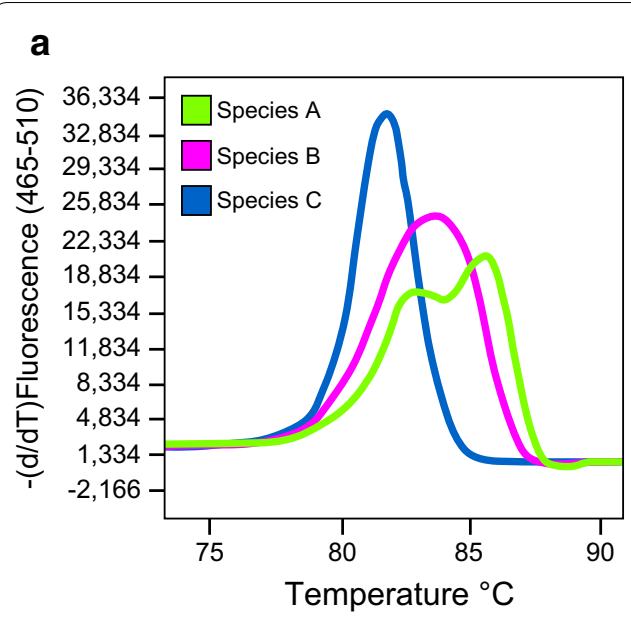

\section{b}

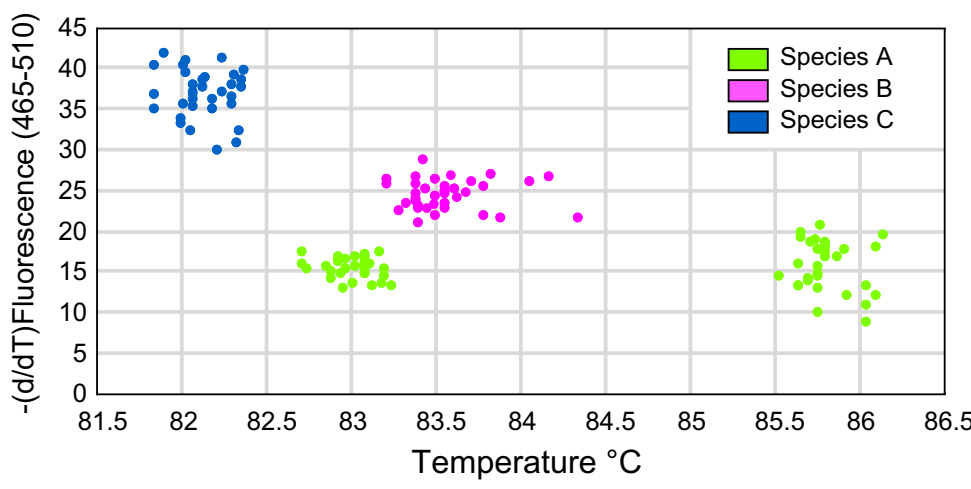

Fig. 2 High resolution melting curve analysis. a A negative first-derivative plot of fluorescence over temperature for three representative individuals of Species A, B, and C (as defined by [5]); redrawn from LightCycler 480 Software. b A 2D scatterplot of melting temperatures at fluorescence peaks for the 100 individuals used to assess the diagnostic value of melting curves for each species

\section{Limitations}

- The method does not provide information about genetic diversity, population structure, or phylogenetic relationships of the study organisms.

- The method is only applicable when background information on the interspecific genetic variation is available for diagnostic markers.

\section{Additional file}

Additional file 1. An excel file format containing data used to draw the scatterplot of Fig. 2b.

\section{Abbreviations}

HRM: high-resolution-melting; ND1: NADH dehydrogenase subunit 1 gene fragment.

\section{Authors' contributions}

$\mathrm{DC}, \mathrm{CB}$, and GN conceived and designed the study. CB and RT carried out field sampling and species assignment. RB and RT performed the experiments. DC and RB analysed the data. DC and RB drafted the manuscript. All authors read and approved the manuscript.

\section{Acknowledgements}

We are grateful to Andrea Buffagni and Simone Cardoni for their help with sample collection.

\section{Competing interests}

The authors declare that they have no competing interests.

\section{Availability of data and materials}

Genbank Accession Numbers: MG581893-MG581916.

\section{Consent for publication}

Not applicable.

Ethics approval and consent to participate Not applicable.

\section{Funding}

This research was funded by the University of Tuscia.

\section{Publisher's Note}

Springer Nature remains neutral with regard to jurisdictional claims in published maps and institutional affiliations.

Received: 1 November 2017 Accepted: 21 December 2017 Published online: 08 January 2018

\section{References}

1. Brittain JE. Biology of mayflies. Annu Rev Entomol. 1982;27:119-97.

2. Williams HC, Ormerod SJ, Bruford MW. Molecular systematics and phylogeography of the cryptic species complex Baetis rhodani (Ephemeroptera, Baetidae). Mol Phylogenet Evol. 2006:40:370-82.

3. Lucentini L, Rebora M, Puletti ME, Gigliarelli L, Fontaneto D, Gaino E, et al. Geographical and seasonal evidence of cryptic diversity in the Baetis rhodani complex (Ephemeroptera, Baetidae) revealed by means of DNA taxonomy. Hydrobiologia. 2011;673:215-28.

4. Rutschmann S, Gattolliat JL, Hughes SJ, Baez M, Sartori M, Monaghan MT. Evolution and island endemism of morphologically cryptic Baetis and Cloeon species (Ephemeroptera, Baetidae) on the Canary Islands and Madeira. Freshw Biol. 2014. https://doi.org/10.1111/fwb.12450.

5. Bisconti R, Canestrelli D, Tenchini R, Belfiore C, Buffagni A, Nascetti G. Cryptic diversity and multiple origins of the widespread mayfly species group Baetis rhodani (Ephemeroptera: Baetidae) on northwestern Mediterranean islands. Ecol Evol. 2016;6(21):7901-10.

6. Müller-Liebenau I. Revision der europäischen Arten Gattung Baetis Leach, 1815 (Insecta, Ephemeroptera). Gewässer und Abwässer. 1969:48-49:1-214.

7. Gattolliat JL, Sartori M. What is Baetis rhodani (Pictet 1843)(Insecta, Ephemeroptera, Baetidae)? Designation of a neotype and redescription of the species from its original area. Zootaxa. 2008;1957:69-80.

8. Song H, Buhay JE, Whiting MF, Crandall KA. Many species in one: DNA barcoding overestimates the number of species when nuclear mitochondrial pseudogenes are coamplified. Proc Natl Acad Sci. 2008;105:13486-91

9. Hudson RR, Coyne JA. Mathematical consequences of the genealogical species concept. Evolution. 2002;56:1557-65.

10. Gopaul KK, Sells J, Lee R, Beckstrom-Sternberg SM, Foster JT, Whatmore AM. Development and assessment of multiplex high resolution melting 
assay as a tool for rapid single-tube identification of five Brucella species BMC Res Notes. 2014;7(1):903

11. Madesis P, Ganopoulos I, Anagnostis A, Tsaftaris A. The application of Bar-HRM (Barcode DNA-High Resolution Melting) analysis for authenticity testing and quantitative detection of bean crops (Leguminosae) without prior DNA purification. Food Control. 2012;25(2):576-82.

12. Sambrook J, Fritsch EF, Maniatis T. Molecular cloning: a laboratory manual. 2nd ed. New York: Cold Spring Harbor Laboratory Press; 1989.

13. Salvi D, Schembri PJ, Sciberras A, Harris DJ. Evolutionary history of the Maltese wall lizard Podarcis fiffolensis: insights on the'Expansion-Contraction' model of Pleistocene biogeography. Mol Ecol. 2014;23:1167-87.

14. Salvi D, Bisconti R, Canestrelli D. High phylogeographical complexity within Mediterranean islands: insights from the Corsican fire salamander. J Biogeogr. 2016;43(1):192-203.

15. Bisconti R, Canestrelli D, Nascetti G. Has living on islands been so simple? Insights from the insular endemic frog Discoglossus montalentii. PLOS ONE. 2013;8:e55735.

16. Bisconti R, Canestrelli D, Salvi D, Nascetti G. A geographic mosaic of evolutionary lineages within the insular endemic newt Euproctus montanus. Mol Ecol. 2013;22:143-56.
17. Bauzà-Ribot MM, Jaume D, Fornos JJ, Juan C, Pons J. Islands beneath islands: phylogeography of a groundwater amphipod crustacean in the Balearic archipelago. BMC Evol Biol. 2011;11:211.

18. Bisconti R, Canestrelli D, Nascetti G. Multiple lines of evidence for demographic and range expansion of a temperate species Hyla sarda during the last glaciation. Mol Ecol. 2011;20:5313-27.

19. Bisconti R, Canestrelli D, Nascetti G. Genetic diversity and evolutionary history of the Tyrrhenian treefrog Hyla sarda (Anura: Hylidae): adding pieces to the puzzle of Corsica-Sardinia biota. Biol J Linn Soc. 2011;103:159-67.

20. Buffagni A, Tenchini R, Cazzola M, Erba S, Balestrini R, Belfiore C, et al. Detecting the impact of bank and channel modification on invertebrate communities in Mediterranean temporary streams (Sardinia, SW Italy). Sci Total Environ. 2016;565:1138-50.

\section{Submit your next manuscript to BioMed Central and we will help you at every step:}

- We accept pre-submission inquiries

- Our selector tool helps you to find the most relevant journal

- We provide round the clock customer support

- Convenient online submission

- Thorough peer review

- Inclusion in PubMed and all major indexing services

- Maximum visibility for your research

Submit your manuscript at www.biomedcentral com/submit 